\title{
The 20th Annual Conference of the AMSS
}

\author{
Dearborn, Michigan \\ Rabi' al Akhir 17-19, 1412/October 25-27, 1991
}

The third decade of the Association of Muslim Social Scientists' (AMSS) existence witnessed the collective effort by some of its members to identify major areas for inclusion in its research agenda. Besides taking stock of past performance, the main determinants included those recent events in the ummah which have affected it as a whole and the ensuing problems calling for immediate attention.

Following established tradition, the AMSS and one of its sister professional organizations, the Association of Muslim Scientists and Engineers (AMSE), convened their conferences at the same time and place.

This year's banquet speaker was H.R.H. Crown Prince Hasan bin Talal of Jordan, whose address was delivered in his absence by Mohammad A. Hamadan, former Minister of Education of Jordan. The main thrust of Prince Hasan's address was the need for cooperation among the ummah's various segments in the service of professional and human resource development. The Ismā̄i îl and Lamyả al Fārūqī Memorial Lecture was given by Zafar I. Ansari, Director General, Islamic Research Center, Islamabad, Pakistan. The AMSE keynote speaker was Ali Nayfeh, Virginia Polytechnic Institute and State University, Blacksburg, VA. Nayfeh suggested practical ways of fostering scientific and technological advancement in the ummah through intra-ummah as well as international collaboration.

The main program consisted of seventeen thematic panels organized into eleven sessions. The opening session was chaired by Sayyid M. Syeed, General Secretary of the AMSS. It consisted of the welcome speeches of S. Imtiaz Ahmad, Conference Chair and President of the Islamic Society of North America (ISNA); Sulayman Nyang, President of the AMSS; and Mohammad Zohdy, President of the AMSE. The Convention Chair also read out the felicitous messages received from the White House, the State House, and the local government. The program preview was given by its co-chairs, Mumtaz Ahmad and Dilnawaz Siddiqui (AMSS), and Sayed A. Nassar (AMSE).

The second session had two concurrent panels: 1) "History of Muslim Communities in North America," organized and moderated by Salahuddin Malik, State University of New York (SUNY) at Brockport, Brockport, NY, and 2) "Andragogy: Education of Adults," which was chaired by Mushtaqur Rahman, University of Iowa at Ames, Ames, IA. The history panel featured Anwar Dil, U.S. International University, San Diego, CA, who traced the history of Muslim 
arrival and settlement in the southern California area. Malik dealt with the emergence and current conditions of Muslims in the greater Rochester area in upstate New York. The Chicago-area Muslim community was the subject of the presentation by Asad Hussain, President of American Islamic College, Chicago, IL. Riaz Malik offered an overview of the Muslim communities around Philadelphia.

The panel on andragogy consisted of five presentations. Ola A. Kawi and M. Ridwan, Nova University, FL, presented their Islamic model for assessing adult education needs. Halima al-Zahid, Berkeley, CA, dealt with the topic "The Wives of the Prophet: An Example of Tawhìd." Anne Francisse, Seattle, WA, reflected on a comprehensive curriculum for Muslim adults in choosing spouses in their communities under the present problematic circumstances. S. M. Iqbal, Delaware State Hospital, New Castle, DE, proposed the content and strategies of continuing Islamic education in the West. Idris Jausi, Aminuddin Baki Institute, Kuala Lumpur, Malaysia, investigated community education from an Islamic perspective.

The third session was composed of three concurrent panels: 1) "Communication and Cultural Issues," moderated by Ali Ramadan, International Institute of Islamic Thought; 2) "The State-of-the-Art Round Table on Islamic Studies in Pakistan," moderated by Anwar H. Siddiqui, Vice President, International Islamic University, Islamabad, Pakistan; and 3) "Islamic Education in America: From Theory to Practice," moderated by Sulayman Nyang, Howard University, Washington, DC. The third panel featured a presentation by M. Amir Ali, Institute of Islamic Information \& Education, Chicago, IL. He exposed the unIslamic character of the religion preached and practiced by the Nation of Islam's Louis Farrakhan and expressed his pessimism about any potential for reform in line with orthodox Islam.

The round table included interactive presentations by a strong contingent of professionals from Pakistan: Anwar H. Siddiqui, Vice President, International Islamic University (IIU), Islamabad; M. Akhtar Saeed Siddiqui, University of Karachi, Karachi; Khalid Ikramullah Khan, Assistant Secretary General, World Muslim Congress, Karachi; Jamila Suddal, Peshawar University, Peshawar; Ghulam Zainab Bano, Frontier College for Women, Peshawar; Mohammad Amin, Arqam Foundation, Karachi; and Jamila Shaukat, University of Punjab, Lahore. They shared with their audience the problems and prospects of Islamic studies in Pakistan.

The fifth panel dealt with the theories and practices of Islamic education and teacher preparation in America. Hakim M. Rashid, Howard University, Washington, DC, compared and contrasted the prevailing and predominant Western schools of thought and theories of child development with those based on Islamic principles. His conclusion was that the latter were superior to the former. Quadir A. Sabur, Muslim Teacher's College, Tomville, VA, traced the 
evolution and operation of the peripatetic college of education for preparing Islamically oriented teachers suited to the American socioeconomic milieu.

The capstone event of the day was a panel discussion on the mosque's comprehensive role in a Muslim community's life. This was organized and chaired by Abdul Moniem Shaker. The speakers included Jamal Badawi, Halifax, NS, Canada; Munir Fareed, Detroit, MI; A. Munim Khattab, Toledo, OH; M. Musa; and Siraj Wahaj, New York, NY. All of these eloquent Islamic scholars emphasized the need for involving Muslim women and youth in community affairs through the activities undertaken by the mosque as a dynamic Islamic institution rather than as a mere place of ritual worship.

The fourth session consisted of two concurrent panels: 1) "The Gulf War and Related Issues," chaired by Mumtaz Ahmad, Hampton University, Hampton, VA, and 2) "Social Sciences: Theoretical Issues," moderated by M. M. Ali, University of the District of Columbia, Washington, DC. Dilnawaz A. Siddiqui, Clarion University of Pennsylvania, Clarion, PA; Abbas al-Khafaji, Slippery Rock University of Pennsylvania, Slippery Rock, PA; and Sharaf N. Rahman, Northern State College, Aberdeen, SD, presented papers on the Gulf War and the misrepresentation of Muslims and Islam in the Western media. Siddiqui analyzed the media's agenda-setting role and the evidence to show how the Gulf War led to the establishment of the long-planned pax americana. Al-Khafaji covered the general and specific issues and the aftermath of the war, showing the war's manifest and latent costs to both sides, and argued that the dispute could have been resolved without recourse to war if the parties had shown the readiness to do so. Rahman's paper illustrated the media's image-making function in generating negative perceptions of Muslims and Islam among Western people.

Panel seven included three presentations. The one by Khalid bin Sayeed, Queen's University at Kingston, Kingston, ON, Canada, offered an in-depth investigation into the interface between Islamic intellectual thought and the challenge of Western ideologies. Mohammad Shafiq, Peshawar University, Peshawar, Pakistan, compared the Islamization of knowledge models and strategies of Ismāîi al Fārūqī, S. Hosein Nasr, and Fazlur Rahman. Abdul Ghani Khalafullah, University of Cairo (Emeritus), Cairo, Egypt, proposed a paradigm for Islamic scholars in America relevant to the formulation of ummatic issues in the post-Cold War period.

The fifth meeting was a plenary session devoted to the theme of the conference. Țāhā J. al 'Alwānī and Mona Abul-Fadl, both of the International Institute of Islamic Thought, Herndon, VA, were the focus presenters. Al 'Alwāni investigated the current state of the Islamic social sciences and proposed an issue-based research agenda for the coming decades, while Abul-Fadl clearly spelled out the lessons learned from the efforts to Islamize various disciplines and offered practical strategies to reconstruct some of the social sciences.

The seventh session was composed of three concurrent panels: 1) "The 
Muslim Community: Sociological Perspectives," chaired by Ilyas Ba-Yunus, SUNY-Cortland, Cortland, NY; 2) "Economics and Human Resources," chaired by Anwar H. Siddiqui, International Islamic University, Islamabad, Pakistan; and 3) "Public Education System and Images of Islam," moderated by M. Akhtar S. Siddiqui, Karachi University, Karachi, Pakistan. Sulaiman M. Bah, University of Western Ontario, London, ON, Canada, explored the prospects for developing an Islamic demography model in terms of methods, materials, and concerns, while Ilyas Ba-Yunus shared the findings of his ongoing empirical study on the demographic structure of Muslims in North America. Sulayman Nyang gauged the impact of Muslim immigration on the Christian-Muslim dialogue in the United States. Saddeka Arebi, University of California-Berkeley, Berkeley, CA, analyzed the West's effect on gender construction in the contemporary religious discourse on defining Islam and the cultural agenda for Muslims. She illustrated how the language and content of the writings of many renowned Muslim scholars have been influenced by Western terminology.

On panel ten, Mohammad Farooq, Western Illinois University, Macomb, IL, analyzed the processes of change and continuity as dynamics of institutional behavior, with a special focus on economically less-developed Muslim societies. Ghouse Shareef, Bellarmine College, Louisville, KY, offered a practical model for developing Islamic behavior with a view to building a meaningful ummah, and illustrated its cognitive and neurophysiological bases. Ghulam Haniff, St. Cloud University, St. Cloud, MN, documented the pathological state of Muslim human resources in terms of literacy rates, school enrollments, and managerial as well as technological skills. He warned that this lack of preparedness has placed Muslim development at serious risk.

Panel eleven featured three presentations. A. Rahim Mahmood, Islamic Cultural Protection and Information Committee, Millbourne, PA, recorded the experiences of Muslims who face negative imagery about Islam in American schools. Shában Ismail, Department of Education, ISNA, Plainfield, IN, shared his observations on the nature of the American public education system's coverage of Islam and Muslims. Amir Ali, IIIE, Chicago, IL, offered an illustrative analysis of the stereotypical images of Islam in American public schools.

The eighth session comprised two concurrent panels: 1) "The New World Order," moderated by Muhammad A. Khan, Peshawar University, Peshawar, Pakistan; and 2) "The Shari'ah and Islamic Movements," moderated by Jamila Shaukat, Punjab University, Lahore, Pakistan. As part of panel twelve, Hasan Ali, University of North Texas, Denton, TX, explicated the new world order and its implications for the Islamic world. This panel also included a presentation by Yusuf Azami, Osmania University, Hyderabad, India, on the problems and prospects faced by Islam in the present age and the potential contribution of Islam to bringing about a new world order. Mohammad A. Siddiqi, Western Illinois University, Macomb, IL, analyzed the communication and informa- 
tion policies of Egypt, Malaysia, and Pakistan. He expressed concern about the West's onslaught through entertainment programs imported by these Muslim nations, as these nations still have many loopholes in their haphazard mass media policies. He suggested several constuctive ways of formulating and implementing a mass communication policy.

Panel thirteen consisted of three papers. The first one, by Yusuf Kavakci, Islamic Association of North Texas, Richardson, TX, spelled out the protocol of proclaiming a fatwa and the system of Islamic interpretation as a means of applying Islamic law in the United States. Taysir Nashif, Essex County College, Newark, NJ, reflected on the territorial significance of alladhì bārakna hawlahu in the first verse of Surat al Isrā'. Riad Adhami, Corona, CA, explained a schema for prioritizing Shari'ah rulings based on Imam Shatibi's work.

The tenth session included two concurrent panels: 1) "Social Science Research Analysis" and 2) "Political Governance, Public Reaction, and Freedom of Expression." On panel fourteen, Hassan Yahya, Lansing Community College, Lansing, MI, identified problems and suggested possible solutions in the context of the social science disciplines. Akhtar Emon, The Islamic Center of South Bay, CA, stressed the need for conducting a Qur'an census in terms of its awareness among various segments of the Muslim population. Hassan Mneimneh, Harvard University, Cambridge, MA, investigated the neutrality of a computer by conducting an inquiry into its cultural bias. Panel fifteen featured four rather diverse presentations. Mumtaz Ahmad, Hampton State University, Hampton, VA, analyzed the differential in the reactions of various Islamic groups to the Gulf War and its socioeconomic and political reasons. Abid Al-Marayati, University of Toledo, Toledo, $\mathrm{OH}$, exposed the sophisticated ways and means of suppressing academic freedom in America and called the existence of such a freedom a myth rather than a reality. Louay Safi, Wayne State University, Detroit, MI, discussed the status of nationalistic movements among Muslims in mixed population areas. Fawzia Bariun, University of Michigan-Detroit, Detroit, MI, delineated the feasibility of an Islamic agenda in the face of various challenges and choices for Muslims.

The eleventh session was the last of the conference and had two concurrent panels: 1) "Islamic Curricular Issues" and 2) "New Directions in History." In the first of these, Dawood A. Adeyola, Islamic Academy, West Valley, NY, analyzed the principles behind the process of Islamic education from the perspectives of the internal and external stimuli to the child's innocent nature. He then dealt with the child's responsible response patterns developed by a truly Islamized instructional system. Tasneema Ghazi, Iqra International Foundation (IIF), Chicago, IL, discussed and illustrated the interrelated elements of her Islamic education model. She also informed the audience about the current status of her continued curriculum development project(s). Abidullah Ghazi, also of IIF, Chicago, IL, shared a comprehensive program of Islamic 
curricular and instructional development for various parts of the world, with a particular emphasis on the local needs in the West. Assad Busool, American Islamic College, Chicago, IL, shared his experiences in and efforts at negotiating with school boards and publishers of curricular and instructional materials for the American public school system to pull offensive and unauthentic sources on Islam from school courses and textbooks and replace them with accurate information. In panel seventeen, organized by Aftab A. Khan, Buffalo State College, Buffalo, NY, an in-depth discussion occurred on the new directions in the discipline of history. The discussants included, in addition to the organizer himself, A. Moniem Shaker, Wayne County Community College, Detroit, MI, and Robert Delk, Columbia College, Chicago, IL.

The conference also provided a venue for various other academic and professional interest groups. A communications group, the "Muslim Effort to Coordinate Communication Activities (MECCA)," also held discussions among its founding members. Their proceedings are to appear in the news vehicles of their respective organizations. A decision was taken to hold the next year's joint AMSS and AMSE convention at the University of Michigan, Ann Arbor, MI, which is located about thirty miles from Detroit.

Dilnawaz Siddiqui

Professor, Dept. of Communication

Clarion University of Pennsylvania

Clarion, Pennsylvania 